\title{
Surgical Non-Regenerative Treatments for Peri-Implantitis: a Systematic Review
}

\author{
Ausra Ramanauskaite ${ }^{1}$, Povilas Daugela ${ }^{2}$, Ricardo Faria de Almeida ${ }^{3}$, Nikola Saulacic ${ }^{4}$ \\ ${ }^{1}$ Clinic of Dental and Oral Pathology, Lithuanian University of Health Sciences, Kaunas, Lithuania. \\ ${ }^{2}$ Department of Oral and Maxillofacial Surgery, Kaunas University of Medicine, Lithuania. \\ ${ }^{3}$ Department of Oral Surgery and Periodontology, School of Dental Medicine, University of Porto, Porto, Portugal. \\ ${ }^{4}$ Department of Cranio-Maxillofacial Surgery, Faculty of Medicine, University of Bern, Bern, Switzerland.
}

\author{
Corresponding Author: \\ Nikola Saulacic \\ Department of Cranio-Maxillofacial Surgery, Faculty of Medicine \\ University of Bern \\ Freiburgstrasse 10, CH-3010 Bern \\ Switzerland \\ Phone: +4131632 3563 \\ Fax: +41313820279 \\ E-mail: nikola.saulacic@insel.ch
}

\begin{abstract}
Objectives: The purposes of the present study were 1) to systematically review the literature on the surgical non-regenerative treatments of peri-implantitis and 2) to determine a predictable therapeutic option for the clinical management of periimplantitis lesions.

Material and Methods: The study search was performed on primary database MEDLINE and EMBASE from 2005 until 2016. Sequential screenings at the title, abstract, and full-text levels were performed. Clinical human studies in the English language that had reported changes in probing depth (PD) and/or bleeding on probing (BOP) and/or radiologic marginal bone level changes after peri-implantitis surgical non-regenerative treatment at 6-month follow-up or longer were included accordingly PRISMA guidelines.

Results: The first electronic and hand search resulted in 765 citations. From 16 full-text articles reviewed, 6 were included in this systematic review. Surgical non-regenerative methods were found to be efficient in reducing clinical parameters. BOP and PD values were significantly decreased following implantoplasty and systematic administration of antibacterials, but not after local application of chemical compounds or diode laser. Similarly, significant improvement in clinical and radiographic parameters was found only after implantoplasty compared with resective surgery alone. We found significant heterogeneity in study designs and treatments provided among the pooled studies. All of the studies revealed an unclear or high risk of bias. Conclusions: Surgical non-regenerative treatment of peri-implantitis was found to be effective to reduce the soft tissue inflammation and decrease probing depth. More randomized controlled clinical trials are needed to assess the efficacy of surgical non-regenerative therapy of peri-implantitis.
\end{abstract}

Keywords: alveolar bone loss; oral surgery; nonsurgical periodontal debridement; peri-implantitis; review.

\author{
Accepted for publication: 30 August 2016 \\ To cite this article: \\ Ramanauskaite A, Daugela P, Faria de Almeida R, Saulacic N. \\ Surgical Non-Regenerative Treatments for Peri-Implantitis: a Systematic Review \\ J Oral Maxillofac Res 2016;7(3):e14 \\ URL: http://www.ejomr.org/JOMR/archives/2016/3/e14/v7n3e14.pdf \\ doi: $10.5037 /$ jomr.2016.7314
}




\section{INTRODUCTION}

Over the last decades, the use of dental implants has become a standard treatment option to replace missing or hopeless teeth. Several longitudinal studies have reported high survival rates for implants placed, over a period of 10 years [1,2]. Despite of these encouraging data for the use of dental implants in oral rehabilitation, clinicians shell consider several types of complications that may be encountered. Plaqueinduced peri-implantitis is considered one of the most common biological complication [3]. Peri-implantitis can be defined as a clinical condition characterized by an inflammatory reaction that involves the hard and soft tissue, with pathological pocket formation and loss of supporting bone around osseointegrated dental implants $[\underline{4}, \underline{5}]$.

Bacteria accumulation on the implant surface plays an important role in the aetiology of peri-implantitis [6]. The microorganisms essential for the development of infections around dental implants seems similar to the bacteria that cause periodontal diseases. However, recent data pointed to the presence of also very specific microorganisms []]. The sub marginal plaque contains a large variety of Gram-negative anaerobic rods, fusiform bacteria, motile and curved rods as well as spirochetes [ 8$]$ and large amounts of densely packed inflammatory cells that frequently accompanied by a crater-like bone defect surrounding the implant $[\underline{9}, \underline{10}]$. The treatment of peri-implantitis thus aims to arrest the progression of the disease by an anti-inflammatory therapy in order to prevent the progressive loss of supporting bone. Thereafter, periimplant tissues can be re-established and the healthy soft and hard tissues maintained [11]. Actually, many endosseous implants may be successfully used as prosthetic abutments in fully and partially edentulous patients for a prolonged period of time [5]. Nevertheless, numerous aetiological factors may play a decisive role for the progress of infection. The micro and macro design of the implant, the abutment connection, the passive adjustment of the prosthesis and the excessive mechanical load are all related with the disease [12].

Several clinical protocols for treatment of periimplantitis have been proposed, including mechanical debridement, the use of antiseptics and local or systemic antibiotics [13-15], surgical access [16,17], and regenerative [18-20] or resective surgical procedures [21-23]. However, the currently available evidence does not provide any firm or specific recommendations for the surgical therapy of periimplantitis [24]. A recent meta-analyses confirmed that it's possible to obtain a significant reduction in radiological peri-implant marginal bone level using either treatment approaches [25]. The treatment of peri-implant bone loss is thus quite challenging for the clinician.

The purpose of this review is to screen the recent literature on surgical non-regenerative treatment of peri-implantitis. The effectiveness of various surgical non-regenerative treatment modalities was evaluated in relation to the resolution of different clinical and radiographic parameters. Accordingly, this review may help clinicians in the selection of the most appropriate surgical non-regenerative treatment modality.

\section{MATERIAL AND METHODS Protocol and registration}

The review was registered in PROSPERO, an international prospective register of systematic reviews under number CRD42016043320. The methods of the analysis and inclusion criteria were specified in advance and documented in a protocol, accessible through the following link:

http://www.crd.york.ac.uk/PROSPERO/display record.asp?ID=CRD42016043320

The reporting of this systematic analysis adhered to the Preferred Reporting Items for Systematic Review and Meta-Analyses (PRISMA) statement [26].

\section{Focus question}

The following focus question was developed according to the population, intervention, comparison, and outcome (PICO) study design: what are the overall treatment outcomes of surgical nonregenerative procedures applied in the treatment of peri-implantitis lesions?

\section{Types of publications}

The review included clinical studies in humans published in English language. Letters, editorials, case reports, literature reviews, and $\mathrm{PhD}$ theses were excluded.

\section{Types of studies}

The review included all human prospective and retrospective studies and clinical trials, cohort studies, case-control studies, and case series studies published between January 2005 and January 2016, on surgical non-regenerative treatment of peri-implantitis. 


\section{Information sources}

The search strategy for relevant studies comprised the evaluation of electronic databases including Ovid MEDLINE, PubMed, EMBASE and Dentistry and Oral Sciences Source published in the English language. A supplementary hand search of the reference lists performed in dental and implant-related journals limited to English language was carried out to source additional relevant publications for the same time period in following journals: 1) "Journal of Periodontology"; 2) "Clinical Implant Dentistry and Related Research"; 3) "International Journal of Oral and Maxillofacial Implants"; 4) "Clinical Oral Implants Research"; 5) "Implant Dentistry"; 6) "International Journal of Oral and Maxillofacial Surgery"; 7) "Journal of Oral and Maxillofacial Surgery"; 8) "Journal of Dental Research; 9) "Journal of Prosthetic Dentistry"; 10) "International Journal of Prosthodontics"; 11) "Journal of Oral Implantology"; 12) "Journal of Clinical Periodontology"; 13) "International Journal of Periodontics \& Restorative Dentistry"; 14) "European Journal of Oral Implantology".

\section{Search}

The keywords used in the search of the selected electronic databases included the following: "periimplantitis" OR "periimplantitis" OR "peri-implant" OR "periimplant" or ("implant" AND "failure") AND "surgical" OR "treatment" OR "therapy" OR "nonregenerative" OR "nonregenerative" OR "laser" OR "lasers". The choice of keywords was intended to be extensive to collect as much relevant data as possible and to refine the search results, without relying on electronic means alone.

\section{Selection of studies}

The resulting articles were revised by two independent reviewers to ascertain the inclusion and exclusion criteria, compare their decisions and resolve possible differences through discussion. An experienced senior reviewer was consulted when consensus could not be reached. The level of agreement between the reviewers regarding study inclusion was calculated using $\kappa$ statistics. At the title and abstract stage, one reviewer accepted the citations that appeared to meet inclusion criteria and send them to full-text review, with a second reviewer assessing only those citations and abstracts that the first reviewer deemed ineligible. Consequently, a complete independent dual review of full-text articles was undertaken.

\section{Disease definition}

The authors of this review classified peri-implantitis in all cases where there was a clear radiographic threshold $>2 \mathrm{~mm}$ of continuous marginal bone loss beyond biologic peri-implant bone remodelling, presence of bleeding on probing (BOP) and/or suppuration on probing with probing depth (PD) more than $6 \mathrm{~mm}[\underline{3}]$.

\section{Inclusion and exclusion criteria}

The full text of all studies of possible relevance was obtained for assessment against the following inclusion criteria:

- Investigated surgical non-regenerative treatment in patients with at least one osseointegrated screw-shaped dental implant, that presented signs of peri-implantitis;

- Studies involving at least one surgical nonregenerative treatment method of peri-implantitis;

- All human prospective or retrospective followup studies and clinical trials, cohort studies, case-control studies, and case series studies with a minimal sample size of 10 implants and a minimum 6 months of follow-up period;

- Report on clinical and radiographic peri-implant tissues changes, including $\mathrm{PD}$ and/or BOP as primary outcome measure and/or radiographic bone level (RBL) change as secondary outcome measure.

The applied exclusion criteria for studies were as follows:

- In vitro and in vivo studies;

- Studies involving patients with specific systemic diseases, immunologic disorders, uncontrolled diabetes mellitus, osteoporosis, or other implant risk related systemic conditions;

- Studies investigating ceramic or coated implants surface;

- Insufficient information regarding the selected topic;

- Non accessible relevant data, such as impossibility to contact the authors for any reason.

\section{Sequential search strategy}

All article titles were screened to eliminate irrelevant publications considering the exclusion criteria. Next, some studies were excluded based on data obtained after reading the abstracts. At the final stage, the full texts were screened based on the inclusion criteria to confirm the eligibility of each study. 


\section{Data extraction}

The data were extracted and collected from included studies in the form of variables. According to the aim of the present review, the data were arranged as follows:

- "Author (Year)" - revealed the author and year of publication.

- "Type of study" - indicated the type of the study.

- "Sample size" - described the number of patients examined.

- "Detoxification method" - described additional implant surface detoxification measures applied in addition to the instrumental debridement and degranulation.

- "Antimicrobial" - described antimicrobial agents (e.g. systemic antibiotics, chlorhexidine mouth rinse) used adjunctive to the surgery.

- "Probing depth change $(\Delta \mathrm{PD})$ " - described PD difference (in $\mathrm{mm}$ ) before and after surgical treatment.

- "Bleeding on probing change $(\triangle \mathrm{BOP})$ " described BOP difference (in \%) before and after surgical treatment.

- "Radiologic bone level change ( $\triangle \mathrm{RBL}) "$ described the marginal bone level difference (in $\mathrm{mm}$; measured from implant shoulder to the bone surface) before and after the treatment; and/or intrabony defect depth difference (in $\mathrm{mm}$; measured from the bottom of the defect to the interproximal bone) before and after treatment.

- "Follow-up" - described the duration of the observed outcomes.

\section{Risk of bias assessment}

The risk of bias was assessed independently and in duplicate by the two authors during the data extraction process, using the Cochrane Collaboration's two-part tool for assessing risk of bias [27]. The following possible sources of bias were addressed: random sequence generation (selection bias); allocation concealment (selection bias); blinding of participants and personnel (performance bias and detection bias); incomplete outcome data (attrition bias); selective reporting (reporting bias) and other bias (examiner blinding, examiner calibration, standardized probing force, and standardized radiographic assessment). The authors' judgment for each source of bias item was assigned for each study in the data extraction table (Table 1). An overall risk of bias was then assigned to each trial according to Higgins et al. [27]. The degrees of bias were categorized as: (1) low risk, if all the criteria were met; (2) moderate risk, when only one criterion was missing; (3) high risk, if two or more criteria were missing and (4) unclear risk, if too few details were available to make a judgement of certain risk assessment.

\section{RESULTS \\ Study selection}

Article review and data extraction were performed according to the PRISMA flow diagram (Figure 1). The initial search displayed 765 results from the MEDLINE (NCBI PubMed and PMC) and EMBASE databases and 3 results from other sources. A total of 768 search results were initially screened. The inclusion and exclusion criteria were applied to 16 full-text articles.

The $\kappa$ value for inter-reviewer agreement for potentially relevant articles was 1 (titles and abstracts) and $>0.9$ (full-text articles), indicating a "very good" agreement between the 2 reviewers, according to the criteria of Landis and Koch [28].

\section{Study exclusion}

Ten studies were excluded after full-text assessment, being a review paper $(n=7)$ and due to methodological and design faults $(n=3)$.

\section{Study characteristics}

Finally, 6 articles were included in the review $[16,17,21-23,29]$. The summarized individual study characteristics are described in Table 2. A total of 150 patients diagnosed with peri-implantitis were treated in the included studies using different surgical nonregenerative methods.

From the included studies, two were prospective randomized controlled trials $[17, \underline{22}, \underline{23}]$, one was prospective cohort study [16] and two were retrospective controlled studies $[\underline{21}, 29]$. One study included a follow-up period of 6 months [17], three of 1 year $[16,21,29]$ and two up to 3 years $[22,23]$. The mean reported age of the patients ranged from 55 [17] to 61.5 years [21]

All studies included rough surface dental implants. A total of 14 implants treated with respective surgery were lost $[21,29]$. Due to the persisting inflammation, 15 implants had to be removed following resective surgery [21-23]. One implant was removed due to the fracture of the implant neck [29].

Four studies reported on smoking status of the patients, ranging from $25 \%$ [16] to $59.1 \%$ [29]. 
Table 1. Descriptive information of the included studies

\begin{tabular}{|c|c|c|c|c|c|c|c|c|c|c|c|}
\hline Study & \begin{tabular}{|c|} 
Year of \\
publication
\end{tabular} & $\begin{array}{l}\text { Type of } \\
\text { study }\end{array}$ & $\begin{array}{l}\text { Implant } \\
\text { surface }\end{array}$ & Treatment method used & Sample size & Smokers & $\begin{array}{l}\text { Follow-up } \\
\text { (months) }\end{array}$ & $\begin{array}{l}\text { PD changes } \\
\text { Mean (SD) }\end{array}$ & $\begin{array}{c}\text { BOP changes } \\
\text { Mean (SD) }\end{array}$ & \begin{tabular}{|c} 
Radiographic marginal bone level changes/ \\
bone defect fill
\end{tabular} & Comments \\
\hline $\begin{array}{l}\text { Heitz-Mayfield et } \\
\text { al. [16] }\end{array}$ & 2012 & \begin{tabular}{|l} 
Prospective \\
cohort study
\end{tabular} & $\begin{array}{c}36 \text { implants, } \\
\text { rough }\end{array}$ & $\begin{array}{l}\text { Open flap debridement and } \\
\text { implant surface decontaminnation } \\
\text { with saline and with adjunctive } \\
\text { systemic amoxicillin and } \\
\text { metronidazole }\end{array}$ & $\left|\begin{array}{c}24 \text { patients; } \\
\text { mean age } 56\end{array}\right|$ & 0.25 & 12 & 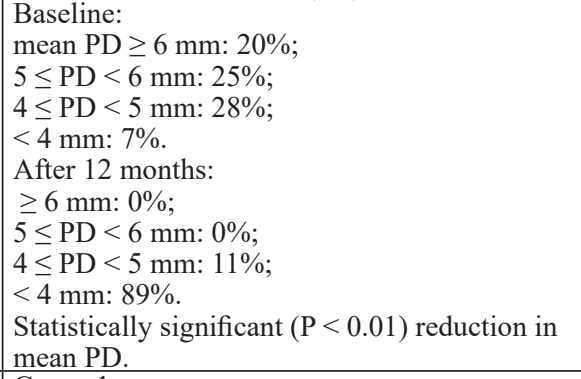 & $\begin{array}{l}\text { Number of sites with BOP: } \\
\text { - baseline: } 2.5(1) ; \\
\text { after 12 months: } 1(1.2) \text {. } \\
\text { Statistically significant }(P<0.01) \text { reduction in } \\
\text { BOP. }\end{array}$ & $\begin{array}{l}\text { Three implants in } 3 \text { patients had } 0.6-1 \mathrm{~mm} \\
\text { bone loss at } 12 \text { months. } \\
\text { Three implants in } 3 \text { patients showed bone } \\
\text { gain, while the remaining implants had stable } \\
\text { marginal bone levels. }\end{array}$ & $\begin{array}{l}\text { Access flap surgery in combination } \\
\text { with systemic antibiotics was an } \\
\text { effective treatment resulting in } \\
\text { significantly reduced BOP and PD } \\
\text { scores. }\end{array}$ \\
\hline $\begin{array}{l}\text { Papadopoulos et } \\
\text { al. [17] }\end{array}$ & 2015 & $\begin{array}{c}\text { Randomized } \\
\text { controlled } \\
\text { clinical study }\end{array}$ & Not known & $\begin{array}{l}\text { Group 1: open flap debridement } \\
\text { alone. } \\
\text { Group 2: open flap debridement } \\
\text { with the edditional use of a diode } \\
\text { laser for the treatment of peri- } \\
\text { implantitis. }\end{array}$ & $\begin{array}{c}\text { 16: age 55. } \\
\text { (40-73) } \\
\text { Group 1: } 8 \\
\text { Group 2: } 8\end{array}$ & Not known & 6 & $\begin{array}{l}\text { Group 1: } \\
\text { - baseline mean PD } 5.92 \mathrm{~mm} ; \\
\text { - after 6 months } 4.44 \mathrm{~mm} ; \\
\text { - reduction of } 1.38 \mathrm{~mm} . \\
\text { Group } 2: \text {. } \\
\text { - baseline mean PD } 5.52 \mathrm{~mm} ; \\
\text { - after } 6 \text { months } 4.31 \mathrm{~mm} ; \\
\text { - reduction of } 1.19 \mathrm{~mm} \text {. } \\
\text { No statistically significant difference between } \\
\text { the 2 groups. }\end{array}$ & \begin{tabular}{|l|} 
Group $1:$ \\
- baseline $93.5 \% ;$ \\
- after 6 months $31.3 \% ;$ \\
- mean reduction $72.9 \%$. \\
Group 2: \\
- baseline $81.2 \% ;$ \\
- after 6 months $23.8 \% ;$ \\
- mean reduction $66.7 \%$ (P $<0.05)$. \\
No statistically significant difference between \\
groups.
\end{tabular} & & $\begin{array}{l}\text { Surgical treatment of peri-implantitis } \\
\text { by access flap surgeryry resulted in } \\
\text { improvenent of clinical parameters. } \\
\text { The addititional use of a diode laser did } \\
\text { not have any extra beneficial effect. }\end{array}$ \\
\hline de Waal et al. [21] & 2013 & \begin{tabular}{|l} 
Retrospective \\
clinical study
\end{tabular} & $\begin{array}{l}79 \text { implants, } \\
\text { rough }\end{array}$ & $\begin{array}{l}\text { Resective surgery with bone } \\
\text { recontouring and surface } \\
\text { decontamination. } \\
\text { GGroup 1: } 0.12 \% \mathrm{CHX}+0.05 \% \\
\text { CPC. } \\
\text { Group 2: placebo. }\end{array}$ & $\begin{array}{l}\text { 30: } \\
\text { Group : } 15 \\
\text { age 61.5 } \\
\text { Group 2: } 15 \\
\text { age 59.4 }\end{array}$ & 46.7 & 12 & 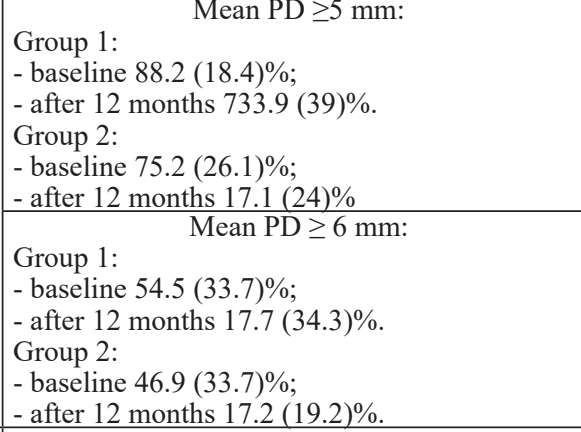 & $\begin{array}{l}\text { Group 1: } \\
\text { - baseline } 87.1(27) \% ; \\
\text { - after 12 months 25.8 }(8) \% . \\
\text { Group 2: } \\
\text { - baseline } 81.3(39) \% ; \\
\text { - after 12 months 15.8 (6)\%. }\end{array}$ & $\begin{array}{l}\text { Group 1: } \\
\text { - baseline 4.3 (2.1) mm; } \\
\text { - after 12 months } 5(2.5) \mathrm{mm} \text {. } \\
\text { Group 2: } \\
\text { - baseline } 3.61(1.9) \mathrm{mm} ; \\
\text { - after 12 months } 3.9(2) \mathrm{mm} .\end{array}$ & $\begin{array}{l}\text { Improved clinical parameters (eg, BOP } \\
\text { and PD) and MBL compared with the } \\
\text { baseline were observed in both groups, } \\
\text { with no significant difference between } \\
\text { them. }\end{array}$ \\
\hline Romeo et al. [22] & 2005 & $\begin{array}{l}\text { Randomized } \\
\text { clinical study }\end{array}$ & $\begin{array}{l}35 \text { implants, } \\
\text { rough }\end{array}$ & $\begin{array}{l}\text { Group 1 (test): resective surgery } \\
\text { and modification of surface } \\
\text { topography (iimplantoplasty). } \\
\text { Group 2: resective surgery only } \\
\text { (control group). }\end{array}$ & \begin{tabular}{|c|}
$17:$ \\
Group 1: 10 \\
Group 2:7
\end{tabular} & 29 & 36 & $\begin{array}{l}\text { Group 1: } \\
\text { - baseline } 5.79(1.69) \mathrm{mm} ; \\
\text { - after } 36 \text { months } 3.21(0.56) \mathrm{mm} \\
\text { (Student's t-value of }+11.63) \text {. } \\
\text { Group 2: } \\
\text { - baseline } 6.52(1.62) \mathrm{mm} ; \\
\text { - after 24 month } 5.5(1.47) \mathrm{mm} \\
\text { (Student's t-value of }+3.18) . \\
\end{array}$ & \begin{tabular}{|l} 
Mean bleeding index: \\
Group 1: \\
- baseline 2.83 $(0.47) ;$ \\
- after 36 months $0.61(0.67)$ \\
(Student's t-value of +16.02$)$. \\
Group 2: \\
- - aseline 2.86 $(0.35) ;$ \\
- after 24 months 2.33 $(0.75)$ \\
(Student's t-value of +3.33$)$.
\end{tabular} & & $\begin{array}{l}\text { Clinical parameters improved in both } \\
\text { treatment groups, without a significant } \\
\text { difference between them. }\end{array}$ \\
\hline Romeo et al. [23] & 2007 & $\begin{array}{l}\text { Randomized } \\
\text { clinical study }\end{array}$ & $\begin{array}{l}38 \text { implants, } \\
\text { rough }\end{array}$ & $\begin{array}{l}\text { Group } 1 \text { (test): resective surgery } \\
\text { and implantoplasty. } \\
\text { Group 2 (control): resective } \\
\text { surgery alone. }\end{array}$ & $\begin{array}{c}\text { 19: } \\
\text { Group 1: } 10 \\
\text { Group 2:9 }\end{array}$ & \begin{tabular}{c|} 
Not \\
reported
\end{tabular} & 36 & & & 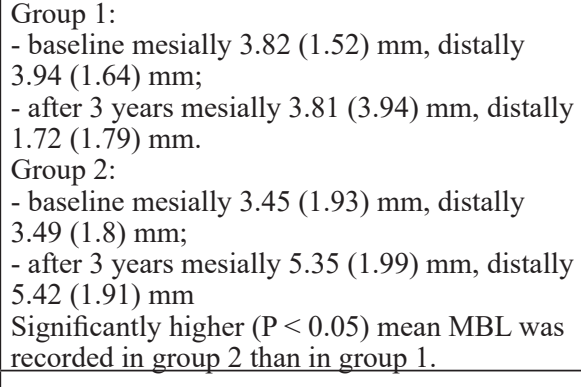 & $\begin{array}{l}\text { A significantly extended MBL } \\
\text { was reported in the group without } \\
\text { implantoplasty. }\end{array}$ \\
\hline de Waal et al. [29] & 2015 & $\begin{array}{l}\text { Retrospective } \\
\text { clinical study }\end{array}$ & $\begin{array}{l}108 \text { implant } \\
\text { rough }\end{array}$ & $\begin{array}{l}\text { Resective surgery with bone } \\
\text { recontouring and uurface } \\
\text { decontamination. } \\
\text { Group 1: } 0.2 \% \text { chlorheksidine } \\
\text { solution. } \\
\text { Group 2: } 0.12 \% \mathrm{CHX}+0.05 \% \\
\text { CPC. }\end{array}$ & $\mid$\begin{tabular}{|c|}
$44:$ \\
Group 1:22 \\
age 6.5 \\
Group 2:22 \\
age 58.6
\end{tabular} & 59.1 & 12 & 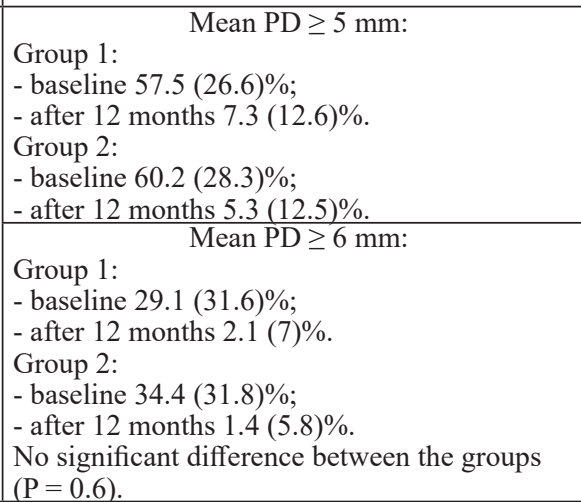 & $\begin{array}{l}\text { Group 1: } \\
\text { - baseline } 82.1(23.9) \% ; \\
\text { - after 12 months } 42.7(34.2) \% . \\
\text { Group 2: } \\
\text { - baseline } 74.2(27.8) \% ; \\
\text { - after 12 month } 37.0(35.3) \% \text {. } \\
\text { No significant difference between the groups } \\
\text { (P = 0.6). }\end{array}$ & $\begin{array}{l}\text { Group 1: Mean MBL: } \\
\text { - baseline } 4(1.5) \mathrm{mm} ; \\
\text { - after 12 months } 4.3(1.7) \mathrm{mm} . \\
\text { Group 2: } \\
\text { - baseline 4.1 }(1.6) \mathrm{mm} ; \\
\text { - atfer 12 months } 4.1(1.7) \mathrm{mm} . \\
\text { Radiologic bone loss was not significantly } \\
\text { different between the groups }(\mathrm{P}=0.8) .\end{array}$ & $\begin{array}{l}\text { Improved clinical parameters (e.g. BOP } \\
\text { and PD) and MBL compared with the } \\
\text { baseline were observed in both groups, } \\
\text { with no significant difference between } \\
\text { them. }\end{array}$ \\
\hline
\end{tabular}

$\mathrm{CPC}=$ Cetylpyridinium chloride; $\mathrm{CHX}=$ chlorhexidine; $\mathrm{MBL}=$ marginal bone loss; $\mathrm{PD}=$ probing depth; $\mathrm{BOP}=$ bleeding on probing . 


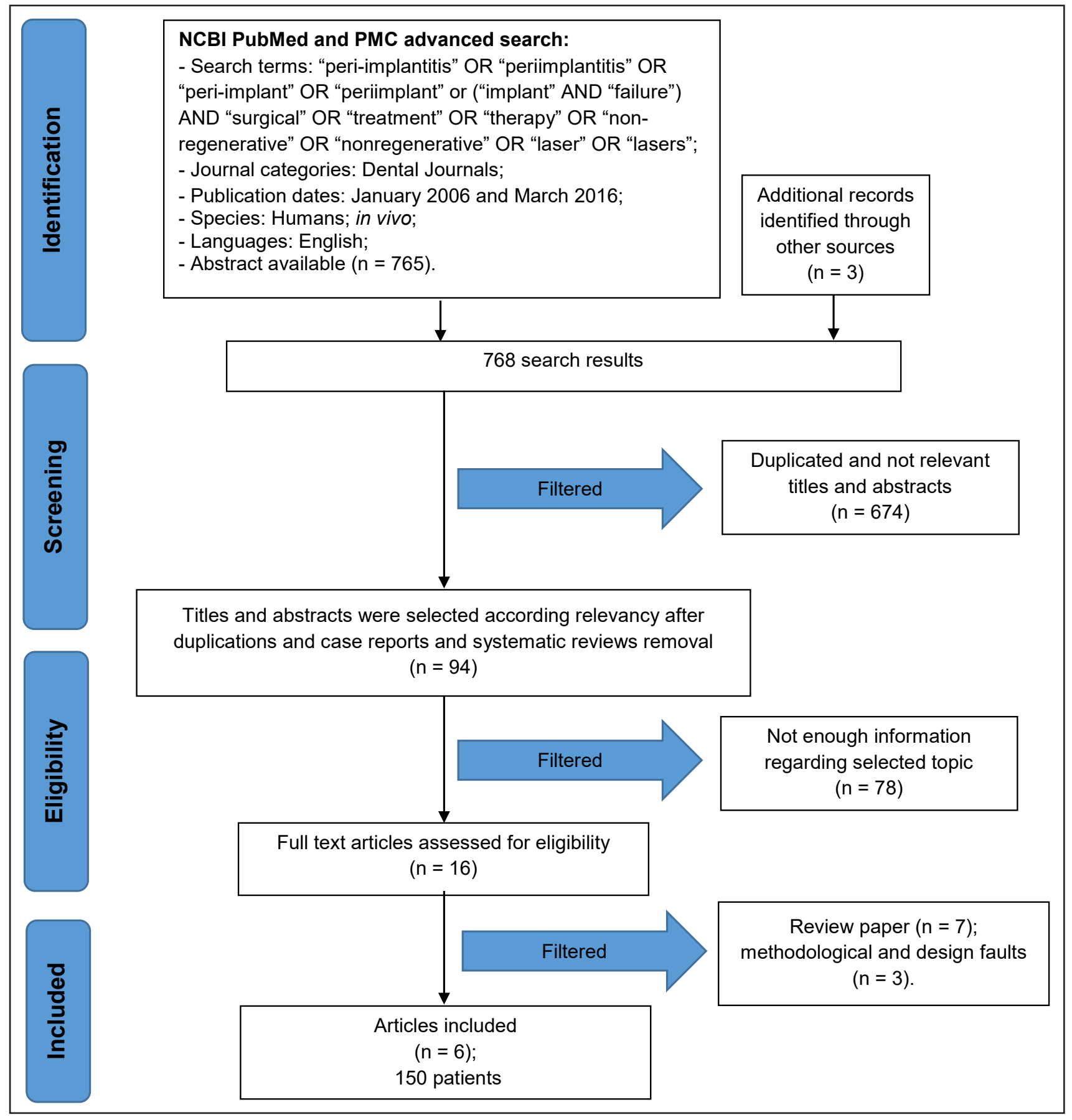

Figure 1. PRISMA flow diagram.

Table 2. Assessment of the risk of bias

\begin{tabular}{l|c|c|c|c|c|c}
\hline \multicolumn{1}{c|}{ Author } & $\begin{array}{c}\text { Random } \\
\text { sequence } \\
\text { generation }\end{array}$ & $\begin{array}{c}\text { Allocation } \\
\text { concealment }\end{array}$ & Blinding & $\begin{array}{c}\text { Incomplete } \\
\text { outcome } \\
\text { data }\end{array}$ & $\begin{array}{c}\text { Selective } \\
\text { reporting }\end{array}$ & $\begin{array}{c}\text { Other } \\
\text { bias }\end{array}$ \\
\hline Heitz-Mayfield et al. [16] & $?$ & $?$ & $?$ & - & - & - \\
\hline Papadopoulos et al. [17] & + & $?$ & + & + & $?$ & + \\
\hline de Waal et al [21] & + & + & + & + & - & + \\
\hline Romeo et al. [22] & - & - & - & + & - & + \\
\hline Romeo et al. [23] & - & - & - & + & - & + \\
\hline de Waal et al. [29] & + & + & + & + & - & + \\
\hline
\end{tabular}

$+=$ low risk; $?=$ unclear risk; $-=$ high risk. 
The study of Heitz-Mayfield et al. [16] showed no negative effect of smoking on treatment outcome. Smoking was, however, relevant for treatment success when for the crude model adjusted for the baseline and time, but not when adjusted for baseline, time smoking, dental status, history of periodontitis and implant surface roughness [21,29].

An improvement in peri-implant clinical parameters was found in four studies using access flap surgery only [17,21-23], surface decontamination with chlorhexidine (CHX) and/or cetylpyridinium chloride (CPC) [21,29] and systemic antibiotics [16]. Significant decrease in BOP scores was showed in studies reporting implantoplasty [22] or use of systemic antimicrobials [16], but not by using CHX with CPC [21,29] or diode laser [17]. Similarly, a significant improvement in PD scores resulted with the addition of implantoplasty [22] or systemic antimicrobials [16], but did not by using the CHX with CPC [21,29] or the diode laser [17].

Initial radiologic bone defect depth was measured in four studies; in three studies the distance was measured from the implant shoulder to the first bone contact $[\underline{21}, \underline{23}, \underline{29}]$ or using landmarks as the threads of the implants [16]. The mean peri-implant bone level at basement ranged from $3.45 \mathrm{~mm}[23]$ to 4.1 $\mathrm{mm}$ [29]. Stable peri-implant bone level was found following systemic application of antibiotics [16] or local use of chemical compounds $[\underline{21}, 29]$.

The addition of chemical compounds $[21,29]$ or diode laser [17] showed no difference in clinical parameters compared to mechanical debridement. On the other hand, implantoplasty demonstrated significant improvement in clinical and radiographic parameters compared to mechanical debridement alone $[\underline{22}, \underline{23}]$.

\section{Risk of bias across studies}

Summarizing the risk of bias for each study, 4 studies were classified as unclear risk (of bias for 1 or more key domains) $[\underline{16}, \underline{17}, \underline{23}]$ and two studies were judged to have a high risk (of bias for more than 1 domain) $[21,22]$. The risk of bias assessment for the included studies is summarized in Table 1.

\section{DISCUSSION}

Present review aimed to assess the overall treatment outcome of surgical non-regenerative procedures applied in the treatment of peri-implantitis lesions. The surgical non-regenerative treatment is a relatively simple procedure, but it depends on various multiple factors including patient general health condition, oral hygiene habits, defect configuration, implant surface characteristics, decontamination procedure, postoperative maintenance program, and various other factors that are not possible to fit within the frames of systematic literature review and meta-analysis. Hereby, we included studies reporting the clinical and/ or radiological outcomes of different surgical nonregenerative treatment methods. Our findings suggest that the effectiveness of peri-implantitis treatment using different surgical non-regenerative modalities is restrained. Reduction of signs of inflammation (decreased BOP index and reduced PD) could be expected and the arrest of continuous bone loss may be expected.

Present findings resemble the statement of the Third European Association for Osseointegration Consensus Conference [30], which claims that peri-implantitis respond well to the surgical non-regenerative treatment, whereas the mechanical debridement alone has limited efficacy. Carbon fiber and/or titanium curettes for debridement are recommended as they cause minimal damage to implant surfaces [31], but the decontamination of the implant surface is considered mandatory for the successful treatment. Different methods were suggested including chemical, mechanical and laser decontaminations [32], aiming the elimination of bacteria and the creation of an implant surface favourable to bone regeneration and re-osseointegration [33]. According to the in vitro study, airflow devices using glycine powders were shown to constitute an efficient therapeutic option for the debridement of implants in peri-implantitis defects [34]. However, we didn't found any study related with the use of airflow devices in surgical non-regenerative surgery. Combined mechanical and chemical removal of biofilm from the implant surface is further recommended [32]. Chlorhexidine digluconate $(0.2 \%)$ and ethylenediaminetetraacetic acid (24\%) demonstrated a considerable decontamination capacity with respect to killing as well to the removal of biofilm cells [35]. The results of the present review indicate that the surface decontamination/debridement using chlorhexidine digluconate reduce bacterial count without significant improvement of the clinical parameters [29]. Furthermore, the suppression of anaerobic bacteria did not lead to better clinical and radiographic outcomes [21]

The majority of surgical protocols include preoperative or postoperative systemic antibiotics followed by postoperative chlorhexidine rinse. The systematic administration of antimicrobials in the study of Heitz-Mayfield et al. [16] contributed in reducing $\mathrm{BOP}$ and $\mathrm{PD}$ by surface decontamination following open flap debridement. 
Wohlfahrt et al. [36] prescribed systemic antibiotics 3 days prior and 7 days after open flap surgery, mechanical debridement, decontamination and placement of the porous titanium granules. Both treatments provided significant clinical improvements in $\mathrm{PD}$, but the reconstruction with porous titanium granules resulted in better radiographic periimplant defect correction. In a recent review, Van Winkelhoff [15] found that there is still a need for randomized clinical trials on the systematic use of antibiotics. Local antibiotic delivery in addition to mechanical debridement and irrigation with an antimicrobial agent may be effective option for treating peri-implantitis lesions [13]. Furthermore, the development of bacterial resistance seems to be very unlikely even in the event of repeated applications [37].

The results of Romeo et al. [23] have demonstrated the advantage of implantoplasty compared to the resective surgery alone in terms of marginal bone preservation in cases with advanced periimplantitis. The implantoplasty was later applied by comparison of Er:YAG laser and saline for implant surface decontamination during combined resective/regenerative surgery; both decontamination methods resulted in significant reduction of BOP and clinical attachment level [마]. Subsequently, positive effects of implantoplasty without implant surface decontamination were confirmed by clinical and radiographic parameters using similar treatment approach [18].

According to the results of this review, the surgical treatment approach should be a treatment option in cases of evident bone loss and pocket formation over $5 \mathrm{~mm}$. Nevertheless, it is evident that successful peri-implant lesion treatment is a comprehensive procedure. The progression of peri-implantitis resistent to the treatment may result in implant mobility. In such cases, the removal of the implant with a successive regenerative procedure is the only therapeutic option [18-23]. As the majority of the studies reporting on regenerative surgical treatments demonstrated significant improvement in clinical parameters and intrabony defect fill, one might suppose that a regenerative approach should be the treatment of choice. Yet, more recently Khoshkam et al. [38] stated a lack of evidence to support the additional benefit of reconstructive therapy as compared to non-reconstructive procedures.

Oral hygiene instructions and the importance of plaque control must be stressed to patients before and after the treatment [39]. Nonsurgical subgingival mechanical debridement in conjunction with local antibacterials, like chlorhexidine digluconate or locally delivered antibiotics are effective in reducing soft-tissue inflammation $[14,40,41]$ and should be the first step in successful treatment. After soft tissue health has been achieved and patient's oral hygiene improved, the treatment could be continued with the surgical step. The supportive treatment phase, by oral hygienists following surgery is an imperative as the last step for the success of peri-implantitis treatment $[\underline{20}, \underline{21}]$. Serino et al. [42] demonstrated that in patients with a high standard of oral hygiene and enrolled in a recall system every 6 months, the peri-implant conditions obtained following periimplant surgery were maintained stable, for the majority of subjects and implants, during a 5-year period.

\section{Limitations}

The evidence of this systematic review was limited to randomized, controlled clinical studies. The revised studies were relatively of short follow-up period and included relatively small numbers of patients. The absence of a control group (without treatment or placebo) was also a limitation. Finally, there were various degrees of heterogeneity in the study design and treatment provided among the pooled studies.

All of the studies included in this review revealed an unclear or high risk of bias. The proportion of information from studies with unclear or high risk of bias may be sufficient to affect the interpretation of results [27]. However, the strength of evidence of this review is low due to the significant variations observed in the included studies.

\section{CONCLUSIONS}

The present systematic review revealed that periimplantitis treatments using different surgical nonregenerative modalities are of limited effectiveness. It can be concluded that the use of implantoplasty or systemic antimicrobials in surgical non-regenerative treatment of peri-implantitis lead to a significant decrease in bleeding on probing and probing depth. Furthermore, the application of chemical compounds or diode laser did not result in significant clinical or radiographic alterations. Implantoplasty may result in improvement in clinical and radiographic parameters compared to mechanical debridement alone. There is limited evidence that a peri-implant bone level may be arrested. Further clinical studies should be conducted for the assessment of complex management and the efficacy of the maintenance protocol. 


\section{ACKNOWLEDGMENTS AND DISCLOSURE STATEMENTS}

The authors have no conflict of interest to disclose.

\section{REFERENCES}

1. Lang NP, Berglundh T, Heitz-Mayfield LJ, Pjetursson BE, Salvi GE, Sanz M. Consensus statements and recommended clinical procedures regarding implant survival and complications. Int J Oral Maxillofac Implants. 2004;19 Suppl:150-4. [Medline: 15635955]

2. Pjetursson BE, Tan K, Lang NP, Brägger U, Egger M, Zwahlen M. A systematic review of the survival and complication rates of fixed partial dentures (FPDs) after an observation period of at least 5 years. Clin Oral Implants Res. 2004 Dec;15(6):667-76. [Medline: 15533127] [doi: 10.1111/j.1600-0501.2004.01120.x]

3. Rosen P, Clem D, Cochran D, Froum S, McAllister B, Renvert S, Wang HL. Peri-implant mucositis and periimplantitis: a current understanding of their diagnoses and clinical implications. J Periodontol. 2013 Apr;84(4):436-43. [Medline: 23537178] [doi: 10.1902/jop.2013.134001]

4. Esposito M, Thomsen P, Ericson LE, Lekholm U. Histopathologic observations on early oral implant failures. Int J Oral Maxillofac Implants. 1999 Nov-Dec;14(6):798-810 [Medline: 10612916]

5. van Steenberghe D, Naert I, Jacobs R, Quirynen M. Influence of inflammatory reactions vs. occlusal loading on peri-implant marginal bone level. Adv Dent Res. 1999 Jun;13:130-5.. [Medline: 11276735] [doi: 10.1177/08959374990130010201]

6. Lang NP, Berglundh T; Working Group 4 of Seventh European Workshop on Periodontology. Periimplant diseases: where are we now?--Consensus of the Seventh European Workshop on Periodontology. J Clin Periodontol. 2011 Mar; 38 Suppl 11:178-81. [Medline: 21323713] [doi: 10.1111/j.1600-051X.2010.01674.x]

7. Belibasakis GN. Microbiological and immuno-pathological aspects of peri-implant diseases. Arch Oral Biol. 2014 Jan;59(1):66-72. [Medline: 24209597] [doi: 10.1016/j.archoralbio.2013.09.013]

8. Mombelli A, van Oosten MA, Schurch E Jr, Land NP. The microbiota associated with successful or failing osseointegrated titanium implants. Oral Microbiol Immunol. 1987 Dec;2(4):145-51. [Medline: 3507627] [doi: 10.1111/j.1399-302X.1987.tb00298.x]

9. Leonhardt A, Renvert S, Dahlén G. Microbial findings at failing implants. Clin Oral Implants Res. 1999 Oct;10(5):33945. [Medline: 10551058] [doi: 10.1034/j.1600-0501.1999.100501.x]

10. Westfelt E, Rylander H, Dahlén G, Lindhe J. The effect of supragingival plaque control on the progression of advanced periodontal disease. J Clin Periodontol. 1998 Jul;25(7):536-41. [Medline: 9696252] [doi: 10.1111/j.1600-051X.1998.tb02484.x]

11. Mombelli A. Criteria for success. Monitoring. In: Lang NP, Karring T, editors. Proceedings of the first European Workshop on Periodontology. London: Quintessence; 1994. p. 317-25.

12. Lang NP, Wilson TG, Corbet EF. Biological complications with dental implants: their prevention, diagnosis and treatment. Clin Oral Implants Res. 2000;11 Suppl 1:146-55. [Medline: 11168263] [doi: 10.1034/j.1600-0501.2000.011S1146.x]

13. Mombelli A, Feloutzis A, Brägger U, Lang NP. Treatment of peri-implantitis by local delivery of tetracycline. Clinical, microbiological and radiological results. Clin Oral Implants Res. 2001 Aug;12(4):287-94. English, French, German. [Medline: 11488856] [doi: 10.1034/j.1600-0501.2001.012004287.x]

14. Renvert S, Lessem J, Dahlén G, Lindahl C, Svensson M. Topical minocycline microspheres versus topical chlorhexidine gel as an adjunct to mechanicaldebridement of incipient peri-implant infections: a randomized clinical trial. J Clin Periodontol. 2006 May;33(5):362-9. [Medline: 16634959] [doi: 10.1111/j.1600-051X.2006.00919.x]

15. van Winkelhoff AJ. Antibiotics in the treatment of peri-implantitis. Eur J Oral Implantol. 2012;5 Suppl:S43-50. [Medline: 22834393]

16. Heitz-Mayfield LJ, Salvi GE, Mombelli A, Faddy M, Lang NP; Implant Complication Research Group. Anti-infective surgical therapy of peri-implantitis. A 12-month prospective clinical study. Clin Oral Implants Res. 2012 Feb;23(2):20510. [Medline: 22092831] [doi: 10.1111/j.1600-0501.2011.02276.x]

17. Papadopoulos CA, Vouros I, Menexes G, Konstantinidis A. The utilization of a diode laser in the surgical treatment of peri-implantitis. A randomized clinical trial. Clin Oral Investig. 2015 Nov;19(8):1851-60. [Medline: 25623382] [doi: 10.1007/s00784-014-1397-9]

18. Matarasso S, Iorio Siciliano V, Aglietta M, Andreuccetti G, Salvi GE. Clinical and radiographic outcomes of a combined resective and regenerative approach in the treatment of peri-implantitis: a prospective case series. Clin Oral Implants Res. 2014 Jul;25(7):761-7. [Medline: 23656191] [doi: 10.1111/clr.12183]

19. Roos-Jansåker AM, Persson GR, Lindahl C, Renvert S. Surgical treatment of peri-implantitis using a bone substitute with or without a resorbable membrane: a 5-year follow-up. J Clin Periodontol. 2014 Nov;41(11):1108-14. [Medline: 25195613] [doi: 10.1111/jepe.12308] 
20. Schwarz F, Hegewald A, John G, Sahm N, Becker J. Four-year follow-up of combined surgical therapy of advanced peri-implantitis evaluating two methods of surface decontamination. J Clin Periodontol. 2013 Oct;40(10):962-7. [Medline: 23931259] [doi: 10.1111/jcpe.12143]

21. de Waal YC, Raghoebar GM, Huddleston Slater JJ, Meijer HJ, Winkel EG, van Winkelhoff AJ. Implant decontamination during surgical peri-implantitis treatment: a randomized, double-blind, placebo-controlled trial. J Clin Periodontol. 2013 Feb;40(2):186-95. [Medline: 23211012] [doi: 10.1111/jepe.12034]

22. Romeo E, Ghisolfi M, Murgolo N, Chiapasco M, Lops D, Vogel G. Therapy of peri-implantitis with resective surgery. A 3-year clinical trial on rough screw-shaped oral implants. Part I: clinical outcome. Clin Oral Implants Res. 2005 Feb;16(1):9-18. [Medline: 15642026] [doi: 10.1111/j.1600-0501.2004.01084.x]

23. Romeo E, Ghisolfi M, Murgolo N, Chiapasco M, Lops D, Vogel G. Therapy of peri-implantitis with resective surgery. A 3-year clinical trial on rough screw-shaped oral implants. Part I: clinical outcome. Clin Oral Implants Res. 2005 Feb;16(1):9-18. [Medline: 17348882] [doi: 10.1111/j.1600-0501.2006.01318.x]

24. Mombelli A, Moëne R, Décaillet F. Surgical treatments of peri-implantitis. Eur J Oral Implantol. 2012;5 Suppl:S61-70. [Medline: 22834395]

25. Ramanauskaite A, Daugela P, Juodzbalys G. Treatment of peri-implantitis: Meta-analysis of findings in a systematic literature review and novel protocol proposal. Quintessence Int. 2016;47(5):379-93. [Medline: 26574611] [doi: 10.3290/j.qi.a35131]

26. Moher D, Liberati A, Tetzlaff J, Altman DG; PRISMA Group. Preferred reporting items for systematic reviews and meta-analyses: the PRISMA statement. J Clin Epidemiol. 2009 Oct;62(10):1006-12. [Medline: 19631508] [doi: 10.1016/j.jclinepi.2009.06.005]

27. Higgins JP, Altman DG, Gøtzsche PC, Jüni P, Moher D, Oxman AD, Savovic J, Schulz KF, Weeks L, Sterne JA; Cochrane Bias Methods Group; Cochrane Statistical Methods Group. The Cochrane Collaboration's tool for assessing risk of bias in randomised trials. BMJ. 2011 Oct 18;343:d5928. [Medline: 22008217] [PMC free article: 3196245] [doi: 10.1136/bmj.d5928]

28. Landis JR, Koch GG. The measurement of observer agreement for categorical data. Biometrics. 1977 Mar;33(1):159-74. [Medline: 843571] [doi: 10.2307/2529310]

29. de Waal YC, Raghoebar GM, Meijer HJ, Winkel EG, van Winkelhoff AJ. Implant decontamination with $2 \%$ chlorhexidine during surgical peri-implantitis treatment: a randomized, double-blind, controlled trial. Clin Oral Implants Res. 2015 Sep;26(9):1015-23. [Medline: 24861411] [doi: 10.1111/clr.12419]

30. Klinge B, Meyle J; Working Group 2. Peri-implant tissue destruction. The Third EAO Consensus Conference 2012. Clin Oral Implants Res. 2012 Oct;23 Suppl 6:108-10. [Medline: 23062134] [doi: 10.1111/j.1600-0501.2012.02555.x]

31. Louropoulou A, Slot DE, Van der Weijden FA. Titanium surface alterations following the use of different mechanical instruments: a systematic review. Clin Oral Implants Res. 2012 Jun;23(6):643-58. [Medline: 21564303] [doi: $10.1111 / \mathrm{j} .1600-0501.2011 .02208 . x$ ]

32. Mellado-Valero A, Buitrago-Vera P, Solá-Ruiz MF, Ferrer-García JC. Decontamination of dental implant surface in peri-implantitis treatment: a literature review. Med Oral Patol Oral Cir Bucal. 2013 Nov 1;18(6):e869-76. [Medline: 23986023] [PMC free article: 3854079] [doi: 10.4317/medoral.19420]

33. Mombelli A. Microbiology and antimicrobial therapy of peri-implantitis. Periodontol 2000. 2002;28:177-89. [Medline: 12013341] [doi: 10.1034/j.1600-0757.2002.280107.x]

34. Sahrmann P, Ronay V, Sener B, Jung RE, Attin T, Schmidlin PR. Cleaning potential of glycine air-flow application in an in vitro peri-implantitis model. Clin Oral Implants Res. 2013 Jun;24(6):666-70. [Medline: 22409152] [doi: $10.1111 / \mathrm{j} .1600-0501.2012 .02445 . x]$

35. Ntrouka V, Hoogenkamp M, Zaura E, van der Weijden F. The effect of chemotherapeutic agents on titanium-adherent biofilms. Clin Oral Implants Res. 2011 Nov;22(11):1227-34. [Medline: 21320167] [doi: $10.1111 / \mathrm{j} .1600-0501.2010 .02085 . \mathrm{x}]$

36. Wohlfahrt JC, Aass AM, Granfeldt F, Lyngstadaas SP, Reseland JE. Sulcus fluid bone marker levels and the outcome of surgical treatment of peri-implantitis. J Clin Periodontol. 2014 Apr;41(4):424-31. [Medline: 24417563] [doi: $10.1111 /$ jepe.12229]

37. Raghavendra M, Koregol A, Bhola S. Photodynamic therapy: a targeted therapy in periodontics. Aust Dent J. 2009 Sep;54 Suppl 1:S102-9. [Medline: 19737261] [doi: 10.1111/j.1834-7819.2009.01148.x]

38. Khoshkam V, Chan HL, Lin GH, MacEachern MP, Monje A, Suarez F, Giannobile WV, Wang HL. Reconstructive procedures for treating peri-implantitis: a systematic review. J Dent Res. 2013 Dec;92(12 Suppl):131S-8S. [Medline: 24158331] [PMC free article: 3860060] [doi: 10.1177/0022034513509279]

39. Serino G, Ström C. Peri-implantitis in partially edentulous patients: association with inadequate plaque control. Clin Oral Implants Res. 2009 Feb;20(2):169-74. [Medline: 19077152] [doi: 10.1111/j.1600-0501.2008.01627.x]

40. Renvert S, Lessem J, Dahlén G, Renvert H, Lindahl C. Mechanical and repeated antimicrobial therapy using a local drug delivery system in the treatment of peri-implantitis: a randomized clinical trial. J Periodontol. 2008 May;79(5):836-44. [Medline: 18454662] [doi: 10.1902/jop.2008.070347] 
41. Sahm N, Becker J, Santel T, Schwarz F. Non-surgical treatment of peri-implantitis using an air-abrasive device or mechanical debridement and local application of chlorhexidine: a prospective, randomized, controlled clinical study. J Clin Periodontol. 2011 Sep;38(9):872-8. [Medline: 21770995] [doi: 10.1111/j.1600-051X.2011.01762.x]

42. Serino G, Turri A, Lang NP. Maintenance therapy in patients following the surgical treatment of peri-implantitis: a 5-year follow-up study. Clin Oral Implants Res. 2015 Aug;26(8):950-6. [Medline: 24861154] [doi: 10.1111/clr.12418]

\section{To cite this article:}

Ramanauskaite A, Daugela P, Faria de Almeida R, Saulacic N.

Surgical Non-Regenerative Treatments for Peri-Implantitis: a Systematic Review

J Oral Maxillofac Res 2016;7(3):e14

URL: http://www.ejomr.org/JOMR/archives/2016/3/e14/v7n3e14.pdf

doi: $\underline{10.5037 / j o m r .2016 .7314}$

Copyright $(\odot$ Ramanauskaite A, Daugela P, Faria de Almeida R, Saulacic N. Published in the JOURNAL OF ORAL \& MAXILLOFACIAL RESEARCH (http://www.ejomr.org), 9 September 2016.

This is an open-access article, first published in the JOURNAL OF ORAL \& MAXILLOFACIAL RESEARCH, distributed under the terms of the Creative Commons Attribution-Noncommercial-No Derivative Works 3.0 Unported License, which permits unrestricted non-commercial use, distribution, and reproduction in any medium, provided the original work and is properly cited. The copyright, license information and link to the original publication on (http://www.ejomr.org) must be included. 